Stručni članak

Professional paper

\title{
OBILJEŽJA GOVEDARSKE PROIZVODNJE NA PODRUČJU SISAČKO-MOSLAVAČKE ŽUPANIJE
}

\author{
Marija Vargek, Nikolina Kelava Ugarković, Z. Prpić, K. Salajpal, M. Konjačić
}

\begin{abstract}
Sažetak
Sisačko-moslavačka županija smjestila se u južnom dijelu središnjeg dijela Republike Hrvatske i druga je po veličini županija s obzirom na površinu poljoprivrednog zemljišta.

Stočarstvo je najvažnija grana poljoprivredne proizvodnje uglavnom vezana za pašno držanje životinja (goveda, konji) na području Lonjskog i Odranskog polja. Govedarstvo čini okosnicu stočarske proizvodnje pri čemu dominira simentalska pasmina. Negativni trendovi u kretanju broja goveda na državnoj razini prisutni su i na navedenom području, a odnose se prvenstveno na pad broja mliječnih i kombiniranih pasmina goveda. Tijekom posljednjeg desetljeća raste zanimanje uzgajivača za uzgoj mesnih pasmina goveda što se očituje porastom broja krava svih čistokrvnih mesnih pasmina uključujući i neke koje se nisu ranije uzgajale na području Sisačko-moslavačke županije (salers i aubrak). Također, broj izvornih pasmina bilježi blagi porast u promatranom razdoblju. Navedene promjene pasminske strukture mogle bi poslužiti kao primjer korištenja prirodnih resursa i pašnjačkih površina i na ostalom području Republike Hrvatske.
\end{abstract}

Ključne riječi: Sisačko-moslavačka županija, Lonjsko polje, Odransko polje, mliječne, kombinirane i mesne pasmine goveda

\section{Uvod}

Govedarska proizvodnja se odvija kompleksnim međudjelovanjem goveda i čovjeka u određenom okruženju u cilju proizvodnje animalnih namirnica (mlijeko i meso). Također, govedo je važno i kao dio ekosustava, napasivanjem pomaže u sprečavanju sukcesije i održavanju bioraznolikosti staništa, ali ima i veliku vrijednost kao dio krajobraznog okruženja. Radi svojih anatomskih, etoloških i fizioloških osobitosti, prilagodljivosti i proizvodnosti, govedo je zadržalo dominantnu važnost $u$ animalnoj proizvodnji visokovrijednih namirnica kao i u poljoprivrednoj proizvodnji (Ivanković i Mijić, 2020.). Aktualna govedarska proizvodnja sa sobom nosi i određene dvojbe, kao što je negativan utjecaj na okoliš od kojeg je najvažniji povećanje koncentracije stakleničkih plinova. Današnja govedarska proizvodnja, posebno u gospodarski razvijenim zemljama se dinamično mijenjala te se njome nastoje dijelom pokriti potrebe stanovništva za animalnim proizvodima. Potrošačima je bitna kvaliteta namirnica koje konzumiraju, njihovo porijeklo i sam proces proizvodnje kako bi bili sigurni da konzumiraju zdravstveno ispravan proizvod od životinja kojima se zna porijeklo i sam način uzgoja (Ivanković i Mijić, 2020.).

Marija Vargek, studentica Agronomskog fakulteta, doc. dr. sc. Nikolina Kelava Ugarković, e-mail: nkelava@agr.hr, izv. prof. dr. sc. Zvonimir Prpić, izv. prof. dr. sc. Miljenko Konjačić, prof. dr. sc. Krešimir Salajpal, Agronomski fakultet Sveučilišta u Zagrebu, Svetošimunska cesta 25, 10000 Zagreb, Hrvatska 
Govedarska proizvodnja u Republici Hrvatskoj tijekom posljednjeg desetljeća obilježena je smanjenjem broja krava i isporučitelja mlijeka te je došlo i do određenih promjena u pasminskoj strukturi goveda na pojedinim područjima. Stoga je cilj ovoga rada opisati pogodnosti Sisačko-moslavačke županije u uzgoju goveda, pasminski sastav goveda i njegove promjene tijekom posljednjeg desetljeća.

\section{Prirodna obilježja Sisačko-moslavačke županije}

Sisačko-moslavačka županija smjestila se u južnom dijelu središnjeg dijela Republike Hrvatske, na području na kojem se dotiču Gorska i Panonska Hrvatska. Županija graniči s pet drugih županija: Zagrebačkom, Karlovačkom, Bjelovarsko-bilogorskom, Brodsko-posavskom i Požeško-slavonskom te na jugu s državom Bosnom i Hercegovinom. Zemljopisno ona obuhvaća Posavinu, Banovinu, Moslavinu te dijelove Slavonije i Korduna. Površinom od $4468 \mathrm{~km}^{2}$ spada među najveće županije u Republici Hrvatskoj te zauzima oko 7,9\% kopnenog teritorija Republike. U strukturi ukupne površine, najveći udio čini poljoprivredno zemljište (52\%), zatim šumsko zemljište (44\%) te neplodne površine (4\%). Takva struktura zemljišta predstavlja značajan gospodarski resurs Županije.

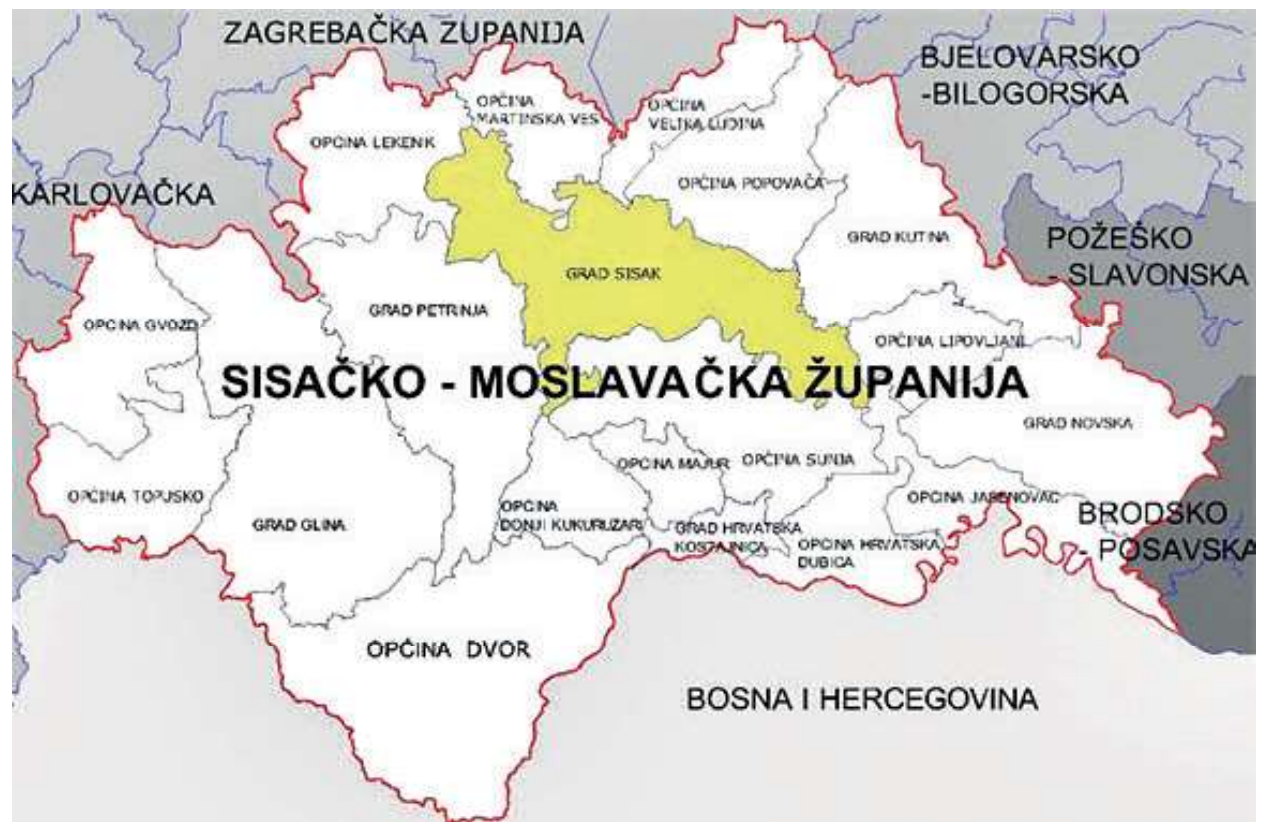

Slika 1. Teritorijalni ustroj Sisačko-moslavačke županije Picture 1 Territorial structure of Sisak-Moslavina County Izvor: (https://sites.google.com/site/hrvatskigradovimm/home/sisacko-moslavacka)

Glavna gospodarska djelatnost na području županije je prerađivačka industrija, s posebnim naglaskom na energetiku, naftnu, petrokemijsku i kemijsku industriju, metalurgiju i metaloprerađivačku industriju, prehrambenu industriju te poljoprivreda i šumarstvo, trgovina, ugostiteljstvo, graditeljstvo, promet i veze (SMŽ - Opći podaci). 
Očuvanost prostora, rijetka naseljenost županije te očuvana tradicijska graditeljska baština daju velike razvojne mogućnosti u razvoju selektivnih oblika turizma (zdravstveni, lovni, seoski i ruralni turizam, cikloturizam te gastroturizam). Posebno obilježje županije i razlog dolaska turista su bogati izvori hipertermalne ljekovite vode (Topusko; SMŽ - Opći podaci).

Prema površini poljoprivrednog zemljišta (236 883 hektara, 53\% površine županije) ona se nalazi na drugom mjestu u RH, odmah iza Osječko-baranjske županije. Od ovoga iznosa 190429 hektara se vodi kao obradiva površina. Također, županija izdvaja znatna sredstva za razvoj ekološke poljoprivrede te je među prvima u RH po broju proizvođača u ekološkoj proizvodnji (SMŽ - Opći podaci).

Na području Županije nalazi se i Park prirode Lonjsko polje. Smješten je u području srednjeg toka rijeke Save, oko 75 km jugoistočno od Zagreba. Čini ga 50650 ha zaštićenog područja uz lijevu obalu rijeke Save, u dužini od oko stotinjak kilometara što ga poslije Velebita čini drugim najvećim zaštićenim područjem (Wattendorf, 2014.). Cijelo područje Parka je izrazito nizinski kraj, a po svom karakteru je poplavno područje s naseljima ruralnog karaktera. Nadmorska visina je od 90 do 110 m. Park je jedno od najvećih i najbolje očuvanih prirodnih poplavnih područja u Europi. Svake godine, vode rijeke Save i njezinih pritoka izlijevaju se u Lonjsko, Poganovo i Mokro polje koji imaju ključnu ulogu u sustavu za obranu od poplava. Park prirode Lonjsko polje je ne samo u Hrvatskoj već i šire jedinstvena zbirka biološke raznolikosti (PP Lonjsko polje - O Parku prirode Lonjsko polje). Najreprezentativnije komplekse šuma listača i u širim razmjerima tj. u cijelom zapadnom palearktiku predstavljaju nizinske poplavne šume hrasta lužnjaka i poljskog jasena. Također, kada se poplavne vode povuku u korito rijeke Save, vlažni travnjaci postaju jedno od posljednjih područja u Europi gdje je sačuvano tradicijsko pašarenje, tako da sva stoka slobodno pase na velikim zajedničkim pašnjacima. Specifičan način tradicionalnog korištenja zemljišta stvaranjem jedinstvenog mozaika antropogenih i prirodnih staništa važnih za očuvanje biološke i krajobrazne raznolikosti oblikovali su ekološki procesi te dinamika plavljenja (PP Lonjsko polje - O Parku prirode Lonjsko polje). Jedinstvenim primjerom prirodnog, krajobraznog i kulturnog naslijeđa ovo područje čine ekstenzivno pašarenje govedima, konjima i svinjama (uključujući i nekoliko autohtonih pasmina poput slavonsko - srijemskog podolca i turopoljske svinje) te očuvanost jedinstvene tradicijske arhitekture drvenih kuća. Temeljne aktivnosti korištenja zemljišta su lov i ribolov, pašarenje, šumarstvo i upravljanje vodama (PP Lonjsko polje - O Parku prirode Lonjsko polje).

Osim Parka prirode Lonjsko polje na području Sisačko-moslavačke županije nalazi se veći dio Odranskog polja. Značajni krajobraz Odranskog polja nalazi se na području Grada Siska, Općine Lekenik te Općine Martinska Ves. U samom zaštićenom području nema stanovnika, no njemu pripadaju obližnja naselja. Prostorna cjelina Odranskog polja i Turopolja smještena je u Posavini tj. aluvijalnoj ravnici uz rijeku Savu na nadmorskoj visini od 95 do $110 \mathrm{~m}$. Ovo poplavno područje prima vodu s okolnih viših terena te ga odlikuju mikroreljefni oblici koji uvjetuju nastanak različitih vlažnih staništa travnjačkih, biljnih i šumskih zajednica koje ovise o režimu plavljenja, ali i o razini podzemne vode. Reljefne karakteristike područja uz Odru uvjetuju formiranje tala koja su prekomjerno vlažena, nalaze se u uvjetima čestih poplava, utjecaju površinskih ili podzemnih voda te dugotrajnom zadržavanju vode i nakon povlačenja poplava (Zaštita prirode SMŽ - Odransko polje). Tradicionalno se na područjima Odranskog polja i Turopolja uslijed prirodnih obilježja bavilo stočarstvom s malim udjelom poljodjelstva, 
uglavnom na rubnim i sušim dijelovima. Specifičnost stočarenja na ovim prostorima odnosila se na dnevne migracije stoke koja se ujutro izvodila na zajedničke pašnjake na ispašu, a navečer se vraćala u staje. Ruralno stanovništvo danas se bavi ekstenzivnim stočarenjem, napasivanjem konja, goveda i svinja. Stoka se pušta na pašnjake tijekom ožujka i travnja, a tek u listopadu ili studenom se vraća u staje (Zaštita prirode SMŽ - Odransko polje). Veliki dio zemljišta koji se nalazi na zaštićenom području je vlasništvo Republike Hrvatske, šumskim zemljištem upravljaju Hrvatske šume d.o.o., a poljoprivredno zemljište se nalazi u nadležnosti državnih agencija koje reguliraju korištenje poljoprivrednog zemljišta. Hrvatske vode zadužene su za upravljanje prostornom cjelinom u sustavu obrane od poplava i drugim djelatnostima koje obuhvaćaju njihov djelokrug rada upravljanja vodama. Privatno zemljište se uglavnom odnosi na rubna područja koja se nalaze neposredno uz naselja (Zaštita prirode SMŽ - Odransko polje). Kulturnu baštinu karakterizira velika očuvanost koja je vidljiva u brojnim objektima tradicijske drvene arhitekture: stambeni, gospodarski te sakralni objekti u naseljima koja okružuju prostornu cjelinu Odranskog polja i Turopolja. Duboka povezanost čovjeka s njegovim zavičajem vidljiva je u kulturnom krajobrazu koji se, premda je rezultat stoljetnog suživota čovjeka i prirode, i dalje čini prirodnim. Također, dio kulturne baštine su i očuvane autohtone pasmine turopoljska svinja i posavski konj kao i tradicijska pasmina posavske guske (Zaštita prirode SMŽ Odransko polje).

\section{Govedarska proizvodnja u Republici Hrvatskoj}

Govedarska proizvodnja u Republici Hrvatskoj posljednjih pola stoljeća prolazila je kroz dinamičnu prilagodbu tržnog i geopolitičkog okruženja, socijalnih trendova te inovacija koje se događaju. Ukupan broj goveda u 2018. godini iznosio je 465 tisuća, od kojih najveći udio čine krave (35\%), zatim telad i mlada junad ( $<1$ god.; 35\%), mlađa junad ( 1 do 2 god.; $22 \%$ ), starija junad (7\%) te bikovi i volovi (1\%). U Hrvatsku se godišnje uveze oko 130 tisuća, a izveze se oko 50 tisuća grla goveda (Ivanković i Mijić, 2020.).

$\mathrm{S}$ obzirom na pasminsku strukturu (odnosno genetsko - proizvodne predispozicije), populacije goveda u Hrvatskoj promijenile su se u suglasju s gospodarsko - tržnim okruženjem. Tako je simentalska pasmina tokom prošlih desetljeća zadržala dominaciju u ukupnoj populaciji goveda, no došlo je do prilagodbe genetskog profila samih pasmina tehnologijama proizvodnje te je došlo do introdukcije određenih inozemnih pasmina goveda (Ivanković i Mijić, 2020.).

U Republici Hrvatskoj prevladavaju mala stada, dok je broj većih i velikih stada mali. Iako je mali broj velikih stada, u njemu se drži relativno veliki broj krava. Samo 0,4\% ukupno broja stada ima više od 100 krava, dok $86 \%$ stada sadrži samo do 10 krava. U stadima koja su u kontroli mliječnosti veći je udio krava u razredima 11-30 krava i >100 krava (HPA, 2018.)

Količina kravljeg mlijeka koje je prikupljeno u 2018. u odnosu na 2017. smanjena je za 4,9\%, što bi količinski značilo da je u 2018. prikupljeno oko 23000 t manje kravljeg mlijeka manje (DZS, 2018.). Broj proizvođača kravljeg mlijeka u negativnom je padu u zadnjih deset godina. 


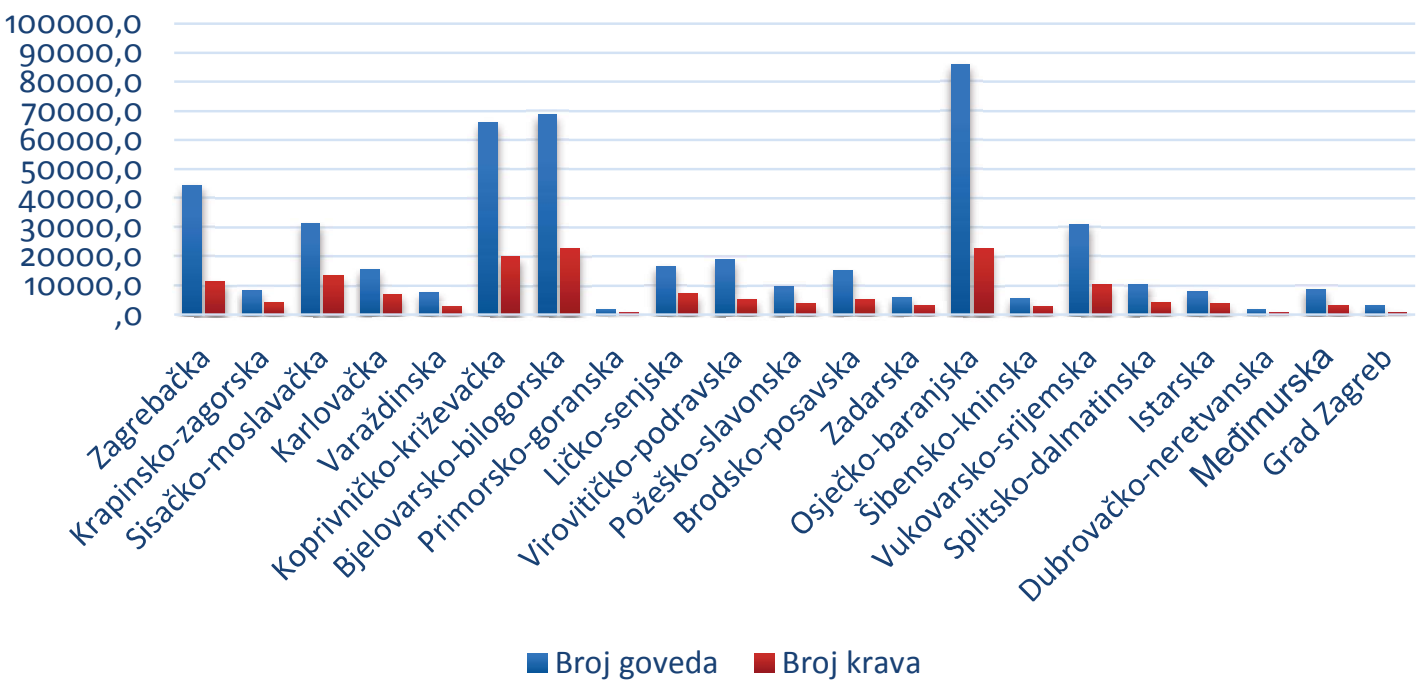

Grafikon 1. Brojno stanje goveda i krava po županijama (2018.)

Graph 1 Number of cattle and cows in Croatian counties (2018)

Izvor: (HPA, godišnje izvješće za 2018. godinu)

Iz grafikona vidljivo je kako Osječko-baranjska županija ima najveći broj goveda (85 802), Bjelovarsko-bilogorska županija ima najveći broj krava 22 852, a na trećem mjestu je Koprivničko-križevačka županija (goveda 66 171, krave 20 098). Na području Sisačkomoslavačke županije tijekom 2018. godine bilo je 31381 goveda i 13574 krava (HPA, 2018.)

\section{Pasminski sastav goveda u Sisačko-moslavačkoj županiji}

Na području Sisačko-moslavačke županije najzastupljenije su kombinirane pasmine goveda koje se uglavnom koriste za proizvodnju mlijeka i mesa.

\section{Simentalska pasmina}

Simentalska pasmina tradicionalno se uzgaja na području Sisačko-moslavačke županije, posebice na području Lonjskog polja. Iz grafikona 2. vidljivo je povećanje broja krava simentalske pasmine tijekom 2010. godine, da bi u kasnijim godinama bio zabilježen lagani pad. Taj negativan trend zaustavljen je tijekom 2018. godine kada je zabilježeno 25 grla više u odnosu na 2017. godinu, a u cijelom promatranom razdoblju od 2009. do 2018. godine simentalska pasmina je zadržala kontinuitet uzgoja tako da je 2018. godine na području Županije simentalskih krava više nego što ih je bilo 2009. godine (za 242 grla). 


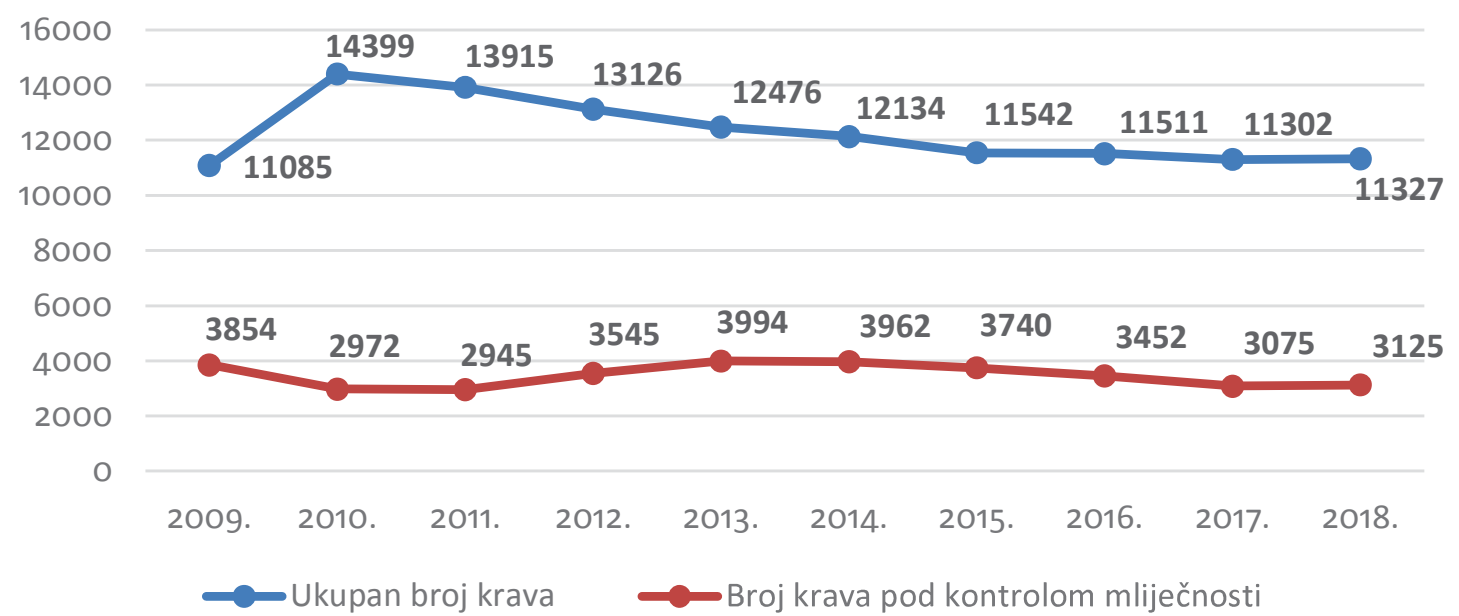

Grafikon 2. Ukupan broj krava i krava u kontroli mliječnosti Simentalske pasmine u Sisačkomoslavačkoj županiji (2009.-2018.)

Graph 2 Total number of cows and cows in dairy control of the Simmental breed in SisakMoslavina County (2009-2018)

Izvor: (https://hpa.mps.hr/publikacije-godisnja-izvjesca/)

\section{Smeđa pasmina}

Za brojnost smeđe pasmine goveda na području predmetne Županije karakteristično je ciklično kretanje tijekom promatranog razdoblja. Broj stalno varira, no mala poboljšanja vidljiva su u 2011. (106 grla više u odnosu na 2010.) i 2014. (55 grla više u odnosu na 2013.) godini. Nakon toga, broj krava je u stalnom padu (grafikon 3.)

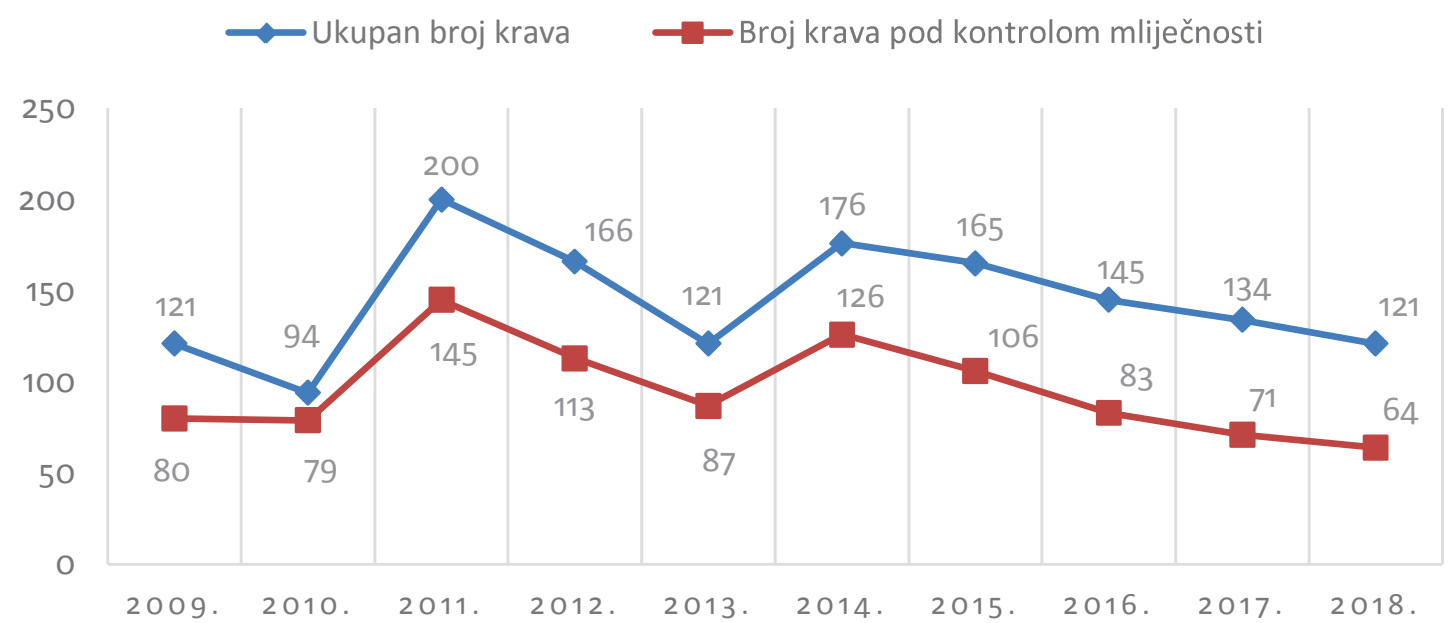

Grafikon 3. Ukupan broj krava i krava u kontroli mliječnosti Smeđeg goveda u Sisačkomoslavačkoj županiji (2009.-2018.)

Graph 3. Total number of cows and cows in dairy control of the Brown Swiss breed in SisakMoslavina County (2009-2018)

Izvor: (https://hpa.mps.hr/publikacije-godisnja-izvjesca/) 
Na području Županije uzgajalo se još i nekoliko grla sive pasmine goveda u razdoblju od 2012. (16 grla) do 2016. godine (8 grla). Nadalje, na prostoru Županije uzgajana je i Montbéliard pasmina goveda tijekom 2009. godine, postojala su 2 uzgajivača sa 100-ak grla. Tijekom 2012. godine na području Županije pojavljuje se i Crveno švedsko govedo no ono je također iščezlo iz navedenog uzgojnog područja.

Od mliječnih pasmina goveda na području Sisačko-moslavačke županije najzastupljenija je Holstein pasmina. Iz Grafikona 4. vidljivo je kako je broj Holstein krava u padu u proteklih 10 godina na području Sisačko-moslavačke županije. Mali porast broja krava vidljiv je 2010 . godine (225 grla u odnosu na 2009. godinu) te je iste godine bio zabilježen i najveći broj krava navedene pasmine (2 316 grla).

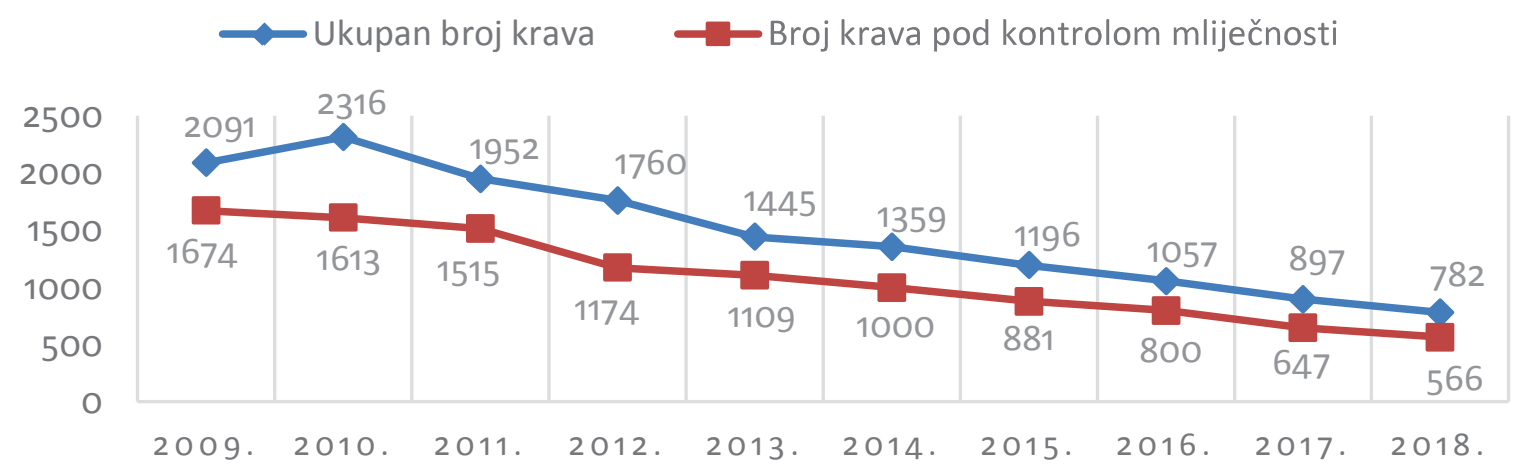

Grafikon 4. Ukupan broj krava i krava pod kontrolom mliječnosti Holstein pasmine u Sisačkomoslavačkoj županiji (2009.-2018.)

Graph 4 Total number of cows and cows in dairy control of the Holstein breed in SisakMoslavina County (2009-2018)

Izvor: (https://hpa.mps.hr/publikacije-godisnja-izvjesca/)

Od mesnih pasmina goveda na području Sisačko-moslavačke županije najzastupljenija je Angus pasmina, a broj krava se povećao u razdoblju od 2009. do 2018. godine sa 24 grla na 197 grla. Sličan rast u promatranom razdoblju prisutan je i u uzgoju Limuzin pasmine goveda. Uzgoj čistokrvne Hereford i Charolais pasmine tijekom promatranog razdoblja obilježen je cikličkim kretanjem, no u obje pasmine je došlo do povećanja broja krava u promatranom razdoblju. Salers goveda su se počela na području predmetne Županije uzgajati od 2013., a Aubrak od 2015. godine i u uzgoju te dvije pasmine primjetan je pozitivan trend iako u apsolutnim brojkama ti uzgoji su relativno mali (grafikon 5.). 


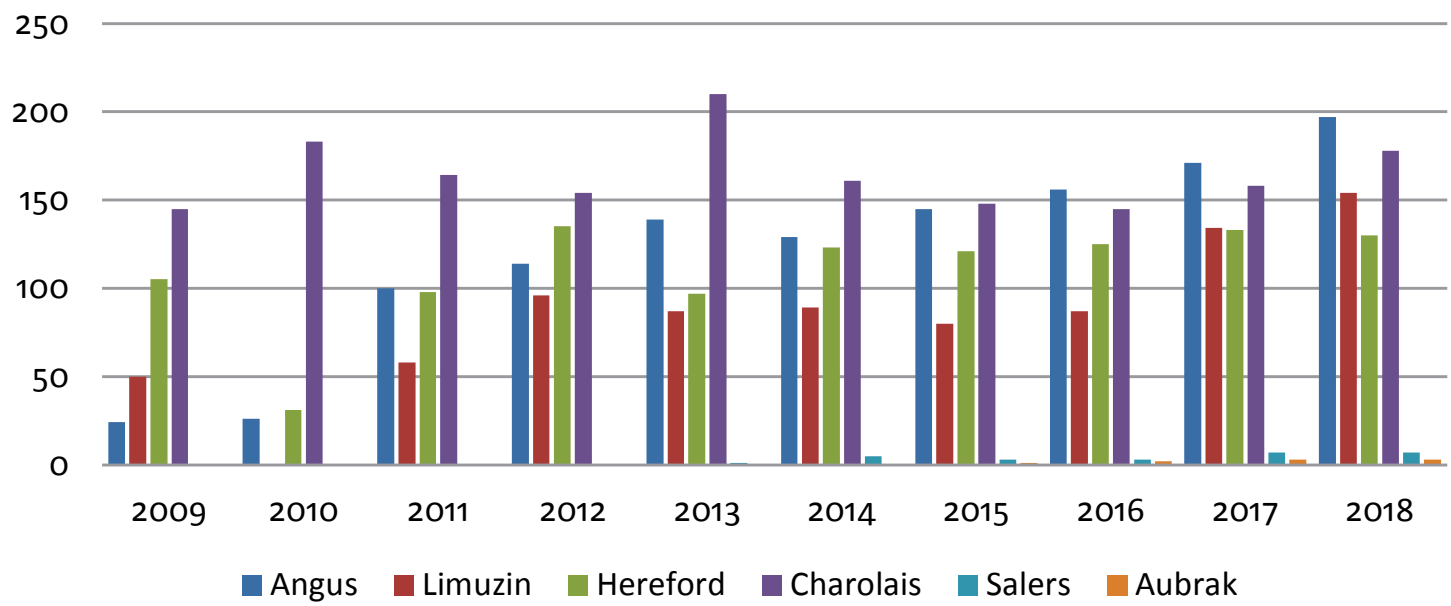

Grafikon 5. Krave mesnih pasmine goveda na području Sisačko-moslavačke županije (2009. -2018.)

Graph 5 Total number of meat breeds cows in Sisak-Moslavina County (2009-2018) Izvor: (https://hpa.mps.hr/publikacije-godisnja-izvjesca/)

Na području Sisačko-moslavačke županije uzgajaju se i sve tri autohtone pasmine goveda. Iako je uzgoj buše na području predmetne županije počeo najkasnije (tijekom 2012. godine) trenutno najveći broj krava zabilježen je upravo za tu pasminu. Uzgoj slavonsko srijemskog podolca obilježen je cikličkim kretanjem u promatranom razdoblju, dok uzgoj istarskog goveda ima lagani rast koji je posebice izražen tijekom posljednjih nekoliko godina (grafikon) 6 .

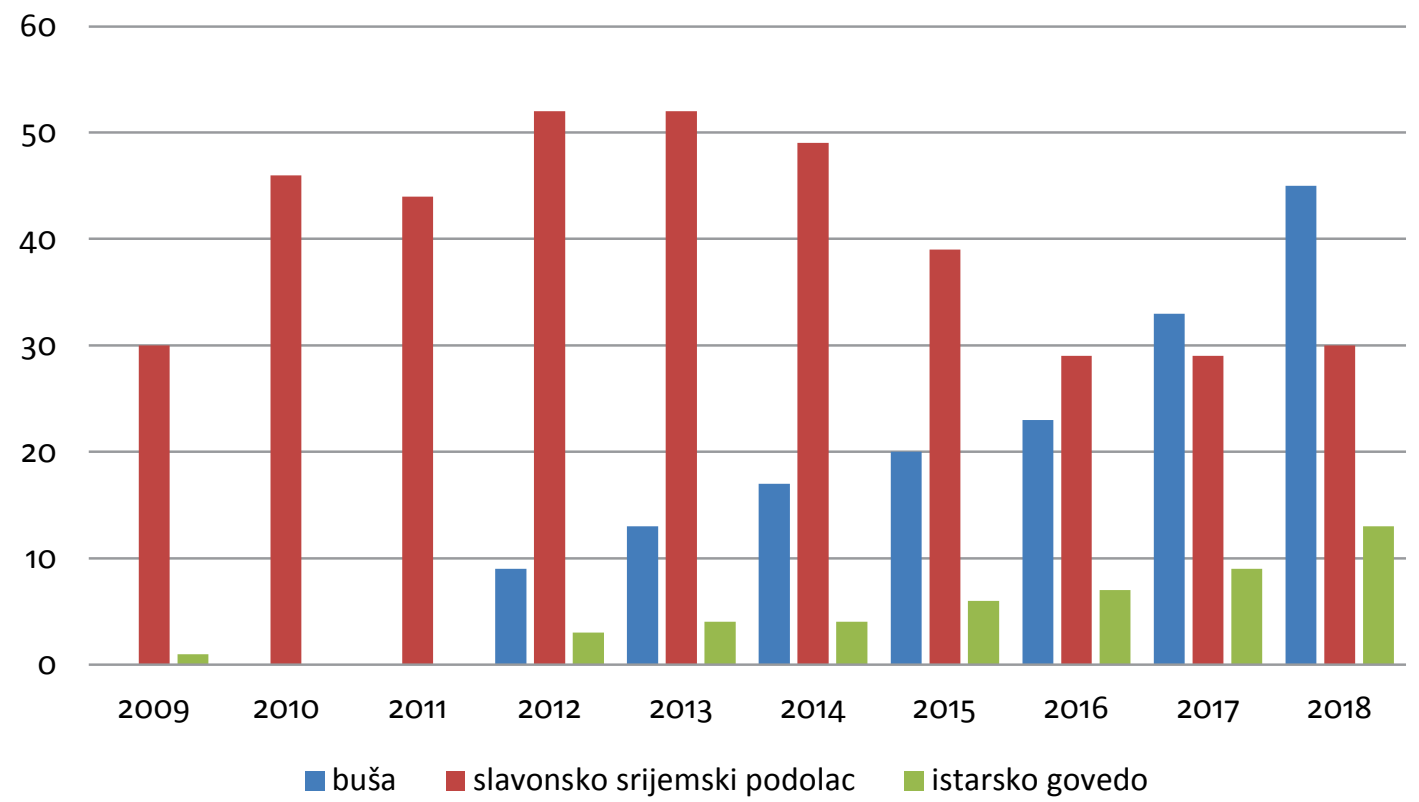

Grafikon 6. Autohtone pasmine na području Sisačko-moslavačke županije Graph 6 Indigenous breeds in the area of Sisak-Moslavina County Izvor: (https://hpa.mps.hr/publikacije-godisnja-izvjesca/) 
Na području Sisačko-moslavačke županije smanjuje se broj krava mliječnih i nekih kombiniranih pasmina te proizvodnja mlijeka. Glavni razlog ovakvog stanja je niska otkupna cijena mlijeka, a i proizvodnja mlijeka je radno intenzivnija nego proizvodnja mesa. Sve više uzgajivača okreće se uzgoju mesnih pasmina, kojima je velika prednost puno jeftinija i jednostavnija proizvodnja. Najveći broj uzgajivača se nalazi na području Lonjskog i Odranskog polja. Velika prednost Lonjskog polja je blizina velikih pašnjačkih površina, na kojima stoka može obitavati vani $7-8 \mathrm{mj}$.

Na području Sisačko-moslavačke županije najveći postotak krava nalazi se u onim stadima gdje se nalazi od 11 - 30 krava u stadu (35\%), dok se najmanji postotak krava nalazi u stadima gdje se nalazi od $101-250$ krava u stadu (6\%). Uzgajivači pretežito drže $1-3$ krave po stadu (67\%), dok je samo 6 stada koja imaju više od 100 krava u stadu $(0,3 \%)$.

U Sisačko-moslavačkoj županiji stočarstvo se smatra važnom granom poljoprivrede te se svake godine raspisuju natječaji za poticaje poljoprivrednicima i stočarima (Grad Popovača, 2020.). Uzgajivačima to pruža značajan poticaj za nastavak uzgoja te održavanje dobre strukture ove strateške grane poljoprivredne proizvodnje.

\section{Zaključak}

Poljoprivredno područje Sisačko-moslavačke županije drugo je po veličini u Republici Hrvatskoj, pri čemu $80 \%$ otpada na obradivo zemljište. Stanovništvo tradicionalnih područja (Lonjsko i Odransko polje) i dalje se bave stočarstvom. Stočarstvo je za ovo područje najvažnija grana poljoprivredne proizvodnje. U zadnjem desetljeću je vidljiv znatan pad ukupnog broja krava no i dalje je najdominantnija simentalska pasmina, koja se tradicionalno uzgaja na području ove županije. Tijekom promatranog razdoblja uočava se porast broja mesnih pasmina goveda. Uzgajivači su uočili veliku prednost uzgoja mesnih pasmina jer uz manja ulaganja i jednostavniju tehnologiju mogu postići veću cijenu po kg žive vage i/ili mesa nego da uzgajaju mliječne i kombinirane pasmine. Također, vidljiv je i manji porast broja krava izvornih pasmina goveda. 


\section{LITERATURA}

1. DZS: Državni zavod za statistiku Republike Hrvatske (2018.): Proizvodnja mlijeka i mliječnih proizvoda u 2018. <https://www.dzs.hr/Hrv_Eng/publication/2019/01-01-25_01_2019.htm>

2. Grad Popovača (2020.): Županija raspisala natječaje za dodjelu poticaja u stočarstvu i poljoprivredi <https://popovaca.hr/vijesti/aktivnosti-udruga/42-vijesti/3411-zupanija-raspisala-natjecaje-za-dodjelu-poticaja-u-stocarstvu-i-poljoprivredi>

3. HPA (2018.): Hrvatska poljoprivredna agencija - Godišnja izvješća za razdoblje od 2009. do 2018 <https://hpa.mps.hr/publikacije-godisnja-izvjesca/>

4. Ivanković i Mijić, (2020.): Govedarstvo. Sveučilište u Zagrebu, Agronomski fakultet, Zagreb

5. Pp Lonjsko polje - O Parku prirode Lonjsko polje <https://pp-lonjsko-polje.hr/o-nama/o-parku/

6. SMŽ - Opći podaci <https://www.smz.hr/opci-podaci>

7. Televizija Radio Banovina - Stočarstvo: Kraljica poljoprivredne proizvodnje <https://www.radio-banovina.hr/stocarstvo-kraljica-poljoprivredne-proizvodnje/>

8. Zaštita prirode SMŽ - Odransko polje <https://zastita-prirode-smz.hr/zastcena-podrucja/odransko-polje/>

9. Wattendorf, P. (2014.): Naturpark Lonjsko polje. Wiley online library <https://onlinelibrary.wiley.com/doi/abs/10.1002/9783527678471.hbnl1999013>

\section{CHARACTERISTICS OF CATTLE PRODUCTION IN THE SISAČKO-MOSLAVAČKA COUNTY}

\section{Summary}

Sisačko-moslavačka county is located in the southern part of the central part of the Republic of the Croatia as a second largest county in relation to amount of agricultural land. Livestock is the most important branch of agricultural sector, mainly related to grazing animals (cattle, horses) in the area of Lonjsko and Odransko fields. Cattle breeding is the backbone of livestock production, dominated by the Simmental breed. Negative trends in the number of cattle are present in this area, and relate primarily to the decline in the number of dairy and dual purpose breeds. Over the last decade, breeders' interest in raising beef cattle breeds has grown which is reflected in the increase in the number of cows of all purebred beef cows including some that were not previously bred in Sisak-Moslavina County (salers and aubrak). Also, the number of native breeds a slight increase in the observed period. These changes in the breed structure could serve as an example of the use of natural resources and pastures in the rest of the Republic of Croatia.

Keywords: Sisačko-moslavačka county, Lonjsko polje, Odransko polje, dairy, combined and meat breeds of cattle

Primljeno: 02.05.2021. Prihvaćeno: 30.06.2021. 